\title{
Influence of Rossby waves on primary production from a coupled physical-biogeochemical model in the North Atlantic Ocean
}

\author{
G. Charria ${ }^{1,2}$, I. Dadou ${ }^{1}$, P. Cipollini' ${ }^{2}$, M. Drévillon ${ }^{3}$, and V. Garçon ${ }^{1}$ \\ ${ }^{1}$ Laboratoire d'Etudes en Géophysique et Océanographie Spatiales, UMR5566/CNRS, Toulouse, France \\ ${ }^{2}$ National Oceanography Centre, Southampton, United Kingdom \\ ${ }^{3}$ CERFACS, MERCATOR-Océan, Toulouse, France
}

Received: 30 October 2007 - Published in Ocean Sci. Discuss.: 29 November 2007

Revised: 9 July 2008 - Accepted: 1 August 2008 - Published: 1 September 2008

\begin{abstract}
Rossby waves appear to have a clear signature on surface chlorophyll concentrations which can be explained by a combination of vertical and horizontal mechanisms. In this study, we investigate the role of the different physical processes in the north Atlantic to explain the surface chlorophyll signatures and the consequences on primary production, using a 3-D coupled physical/biogeochemical model for the year 1998.

The analysis at 20 given latitudes, mainly located in the subtropical gyre, where Rossby waves are strongly correlated with a surface chlorophyll signature, shows the important contribution of horizontal advection and of vertical advection and diffusion of inorganic dissolved nitrogen. The main control mechanism differs according to the biogeochemical background conditions of the area.

The surface chlorophyll anomalies, induced by these physical mechanisms, have an impact on primary production. We estimate that Rossby waves induce, locally in space and time, increases (generally associated with the chlorophyll wave crest) and decreases (generally associated with the chlorophyll wave trough) in primary production, $\sim \pm 20 \%$ of the estimated background primary production. This symmetrical situation suggests a net weak effect of Rossby waves on primary production.
\end{abstract}

\section{Introduction}

The detection of westward propagating signals in surface chlorophyll concentrations related to Rossby waves (e.g. Machu et al., 1999; Cipollini et al., 2001; Uz et al., 2001; Kawamiya and Oschlies, 2001) prompted the question of the underlying physical/biogeochemical inter-

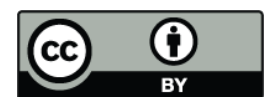

Correspondence to: G. Charria (guillaume.charria@ legos.obs-mip.fr) actions. Based on remotely sensed data and/or coupled physical/biogeochemical modelling, several studies investigated the coupled physical/biogeochemical mechanisms which might be involved (e.g. Charria et al., 2003, 2006a; Killworth et al., 2004). Three main processes were suggested: (1) the upwelling mechanism associated with nutrient injection (Cipollini et al., 2001; Uz et al., 2001; Siegel, 2001), (2) the uplifting of a deep chlorophyll maximum towards the surface (Cipollini et al., 2001; Kawamiya and Oschlies, 2001; Charria et al., 2003), and (3) the meridional advection of chlorophyll by geostrophic currents associated with baroclinic Rossby waves (Killworth et al., 2004). These three processes are described in Killworth et al. (2004) using theoretical models and compared to the remotely sensed observations. These authors pointed out the importance of the third process at the global scale. More recently, Charria et al. (2006a) showed a significant contribution of the vertical process of nutrient injection in the North Atlantic, north of $28^{\circ} \mathrm{N}$, using remotely sensed data and theoretical models from Killworth et al. (2004). However, in the two latter studies, several first-cut approximations were made in the modelling of the biological signal (for example: a constant relaxation time for biology and a constant $\frac{\mathrm{Chl}}{\mathrm{N}}$ ratio). We will investigate here the relative contribution of the different mechanisms using a more realistic 3-D coupled physical/biogeochemical modelling approach.

Furthermore, the influence of Rossby waves on biogeochemical processes has to be estimated for a better understanding of the carbon cycle through the biological pump mechanism. Kawamiya and Oschlies (2001) have found a $\sim 30 \%$ increase in primary production with the passage of a Rossby wave in the Indian ocean around $10^{\circ} \mathrm{S}$ using a coupled physical/biogeochemical model. Near the Hawaiian Ocean Time Series (HOT) station ALOHA in the Pacific Ocean, a combination of in situ high-frequency measurements (shipboard and moored sampling) and remotely sensed data (altimetry) during a long period (1997-1999)

Published by Copernicus Publications on behalf of the European Geosciences Union. 


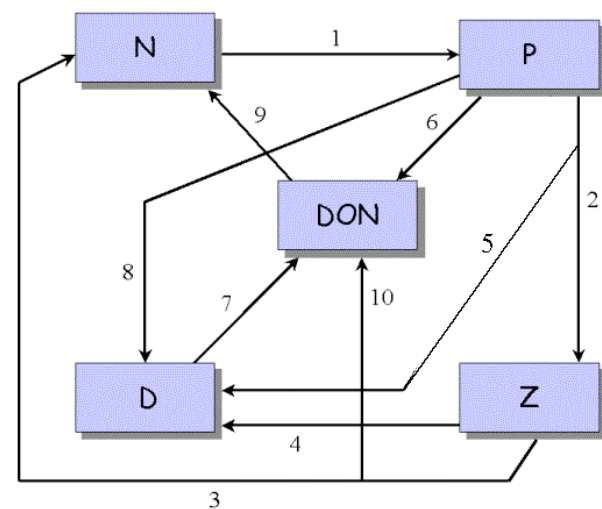

Fig. 1. Dissolved inorganic nitrogen $(\mathrm{N})$, phytoplankton $(\mathrm{P})$, zooplankton (Z), particulate organic matter (D), and dissolved organic nitrogen (DON) model (Huret et al., 2005). The different fluxes between the state variables are: (1) Nutrients assimilation by phytoplankton during photosynthesis, (2) Zooplankton grazing, (3) Zooplankton excretion, (4) Zooplankton mortality, (5) Non-assimilated part of zooplankton grazing (fecal pellets production), (6) Phytoplankton exudation, (7) Particles hydrolysis by bacteria, (8) Phytoplankton mortality, (9) Dissolved organic nitrogen remineralization and (10) Organic zooplankton excretion.

allowed Sakamoto et al. (2004) to estimate primary production enhancement up to $25 \%$ on average due to the Rossby wave's passage. Indeed, Rossby waves can significantly contribute to supply nutrients to oligotrophic surface waters fuelling primary production. According to several authors (e.g. Oschlies and Garçon, 1998; Oschlies, 2002a,b), eddies induce increase in nutrient input into the euphotic layer. Vertical velocities associated with Rossby waves can also induce a similar effect, named as the "Rossby rototiller" (Siegel, 2001), with two crucial differences: 1) the vertical velocities induced by Rossby waves are generally smaller than those in an eddy that is forming or evolving; 2) however, while eddies upwell water only while forming or intensifying, Rossby waves would upwell nutrients all along their propagation path through an ocean basin. This effect is then potentially comparable to basin-scale processes such as induction process in the subpolar gyre (Williams et al., 2006) or Dissolved Organic Nitrogen and Phosphorus advection in the subtropical gyre (Roussenov et al., 2006).

The present work investigates Rossby wave influence on primary production using a 3-D coupled physical/biogeochemical realistic model in the North Atlantic Ocean. After a brief description of the coupled physi$\mathrm{cal} /$ biogeochemical model in Sect. 2, as well as the remotely sensed data used in the validation of simulated wave features in the model (Sect. 3), we will show the surface chlorophyll and physical signatures of Rossby waves using model results. In Sect. 4, the features of these modelled propagating signals are identified and compared to those estimated with remotely sensed data. In Sect. 5, the procedure to extract the studied regions is given, followed by the description of the results in Sect. 6. The influence of Rossby waves on modelled primary production and the relative contribution of the underlying physical/biogeochemical processes in the oligotrophic gyre are discussed in the last section.

\section{A coupled physical/biogeochemical model}

The numerical experiments described here are performed using a 3-D coupled physical/biogeochemical model. The ocean physics is solved by the OPA 8.1 model (Madec and Imbard, 1996) in a North Atlantic configuration (MNATL $20^{\circ} \mathrm{S}-70^{\circ} \mathrm{N}$ and $98.5^{\circ} \mathrm{W}-20^{\circ} \mathrm{E}$ ). This model, initially used in the frame of the CLIPPER project and used by the operational oceanography MERCATOR project, has a $1 / 3^{\circ}$ spatial resolution and 43 vertical levels with a vertical grid spacing increasing from $12 \mathrm{~m}$ at the surface to $200 \mathrm{~m}$ at the bottom. The model grid size has the right spatial resolution to adequately resolve Rossby wave with wavelengths longer than $300 \mathrm{~km}$. For instance, with a $1 / 3^{\circ}$ resolution, there are 10 grid points or more for a $300 \mathrm{~km}$ wavelength wave. Simulations are forced by daily European Centre for Medium-Range Weather Forecasts (ECMWF) atmospheric forcing.

This physical model is coupled with a simple nitrogenbased NPZDDON (dissolved inorganic Nitrogen, Phytoplankton, Zooplankton, Detritus and Dissolved Organic Nitrogen) ecosystem model (Huret et al., 2005). The different fluxes between state variables, represented on Fig. 1 are the following: (1) Nutrients assimilation by phytoplankton during the photosynthesis, (2) Zooplankton grazing, (3) Zooplankton excretion, (4) Zooplankton mortality, (5) Nonassimilated part of zooplankton grazing (fecal pellets production), (6) Phytoplankton exudation, (7) Particles hydrolysis by bacteria, (8) Phytoplankton mortality, (9) Dissolved organic nitrogen remineralization and (10) Organic zooplankton excretion.

The tracer concentrations follow an advective-diffusive equation plus a source-minus-sink (SMS) term of exchange between different tracers. The SMS terms for each of the biological tracer in nitrogen units $\left(\mathrm{mmolN} \mathrm{m}^{-3}\right)$ are:

$$
\begin{aligned}
\operatorname{SMS}(\mathrm{N}) & =\rho \mathrm{DON}+\left(1-f_{2}\right) \gamma \mathrm{Z}-J(z, t, \mathrm{~N}) \mathrm{P} \\
\operatorname{SMS}(\mathrm{P}) & =(1-\epsilon) J(z, t, \mathrm{~N}) \mathrm{P}-\mu_{P} \mathrm{P}-G(\mathrm{P}) \mathrm{Z} \\
\operatorname{SMS}(\mathrm{Z}) & =f_{1} G(\mathrm{P}) \mathrm{Z}-\gamma \mathrm{Z}-\mu_{Z} \mathrm{Z}^{2} \\
\operatorname{SMS}(\mathrm{D}) & =\left(1-f_{1}\right) G(\mathrm{P}) \mathrm{Z}+\mu_{P} \mathrm{P}+\mu_{Z} \mathrm{Z}^{2}-\mu_{D} \mathrm{D} \\
& -w_{S} \frac{\partial \mathrm{D}}{\partial z}
\end{aligned}
$$

$\mathrm{SMS}(\mathrm{DON})=\epsilon J(z, t, \mathrm{~N}) \mathrm{P}+f_{2} \gamma \mathrm{Z}+\mu_{D} \mathrm{D}-\rho \mathrm{DON}$ 
Table 1. Parameters of the ecosystem model.

\begin{tabular}{|c|c|c|}
\hline Symbol & Parameter & Definition \\
\hline \multicolumn{3}{|c|}{ Phytoplankton coefficients } \\
\hline$\alpha$ & $0.025 \mathrm{~d}^{-1} /\left(\mathrm{W} \mathrm{m}^{-2}\right)$ & Initial slope P-I curve \\
\hline PAR & 0.43 & Photosynthetically active radiation coefficient \\
\hline$k_{c}$ & $0.03 \mathrm{~m}^{-1}\left(\mathrm{mmol} \mathrm{m}^{-3}\right)^{-1}$ & Light attenuation by phytoplankton \\
\hline $\mathrm{a}$ & $0.6 \mathrm{~d}^{-1}$ & Maximum growth rate parameters \\
\hline $\mathrm{b}$ & 1.066 & \\
\hline $\mathrm{c}$ & $1\left({ }^{\circ} \mathrm{C}\right)^{-1}$ & \\
\hline $1 / k_{w}$ & $25 \mathrm{~m}$ & 1/Light attenuation due to water \\
\hline$k_{N}$ & $0.5 \mathrm{mmol} \mathrm{m}^{-3}$ & Half-saturation constant for $\mathrm{N}$ uptake \\
\hline$\mu_{P}$ & $0.03 \mathrm{~d}^{-1}$ & Specific mortality rate \\
\hline$\epsilon$ & 0.01 & Exudation fraction of primary production \\
\hline \multicolumn{3}{|c|}{ Zooplankton coefficients } \\
\hline$f_{1}$ & 0.75 & Assimilation efficiency \\
\hline$g$ & $2 d^{-1}$ & Maximum grazing rate \\
\hline$p$ & $1\left(\mathrm{mmol} \mathrm{m}^{-3}\right)^{-2} \mathrm{~d}^{-1}$ & Prey capture rate \\
\hline$\mu_{z}$ & $0.2\left(\mathrm{mmol} \mathrm{m}^{-3}\right)^{-1} \mathrm{~d}^{-1}$ & Mortality rate \\
\hline$\gamma$ & $0.03 \mathrm{~d}^{-1}$ & Excretion rate \\
\hline$f_{2}$ & 0.25 & Organic fraction of excretion \\
\hline \multicolumn{3}{|c|}{ Detritus coefficients } \\
\hline$\mu_{D}$ & $0.23 \mathrm{~d}^{-1}$ & Hydrolysis rate \\
\hline$w_{S}$ & $5 \mathrm{~m} \mathrm{~d}^{-1}$ & Sinking velocity \\
\hline \multicolumn{3}{|c|}{ DON coefficients } \\
\hline$\rho$ & $0.025 \mathrm{~d}^{-1}$ & Remineralization rate \\
\hline
\end{tabular}

$\mathrm{N}$ represents dissolved inorganic nitrogen, $\mathrm{P}$ phytoplankton, $\mathrm{Z}$ zooplankton, $\mathrm{D}$ detritus and DON the semi-labile dissolved organic nitrogen. Parameters are described in Table 1. Parameter values are deduced from Oschlies and Garçon (1999) and Huret et al. (2005), as well as from a preliminary sensitivity analysis (Charria, 2005).

The $J(z, t, \mathrm{~N})$ represents the phytoplankton growth function of light and nutrient limitations. Following the minimum Liebig's Law (Liebig, 1845), the minimum between light and nutrient limitation is used:

$J(z, t, \mathrm{~N})=\min \left(\bar{J}(z, t), J_{\max } L_{\mathrm{NO}_{3}}\right)$

with $\bar{J}(z, t)$ the daily integrated light-limited growth rate, $L_{\mathrm{NO}_{3}}$ the nutrient limitation term, $J_{\max }=a b^{c T}$ the lightsaturated growth rate, $T$ the temperature $\left({ }^{\circ} \mathrm{C}\right), z$ the water depth, and $t$ the daily time.

The nutrient limitation follows the Michaelis-Menten formulation:

$L_{\mathrm{NO}_{3}}=\frac{\mathrm{N}}{\mathrm{N}+K_{N}}$

where $K_{N}$ stands for the half-saturation constant for nutrient uptake.
The light limited growth rate is based on the analytical method from Evans and Parslow (1985). One of the advantages of this method is that a diurnal cycle from daily solar fluxes is simulated analytically. In fact, the light limited growth rate $J(z, t)$ is averaged over $24 \mathrm{~h}$ and over a vertical layer as:

$$
\bar{J}(z, t)=\frac{1}{\tau_{24 h}} \int_{0}^{24 h} \frac{1}{z_{k}-z_{k-1}} \int_{z_{k-1}}^{z_{k}} J\left(z, t^{\prime}\right) d z d t^{\prime}
$$

where

$J\left(z, t^{\prime}\right)=\frac{J_{\max } \alpha I\left(z, t^{\prime}\right)}{\left(J_{\max }^{2}+\alpha^{2} I\left(z, t^{\prime}\right)^{2}\right)^{1 / 2}}$

where $I\left(z, t^{\prime}\right)$ is the local light intensity and $\alpha$ the initial slope of the photosynthesis-light (P-I) curve. Using these equations ( 8 and 9 ), the light is maximum at noon at surface (it decreases exponentially with depth). Evans and Parslow (1985) then compute analytically the limitation term integrated over the mixed layer depth and during the day, and found the following equation:

$$
\begin{array}{r}
\bar{J}\left(z, t^{\prime}\right)=\frac{2 J_{\max }}{k M}\left[F\left(\beta e^{k M}, \tau\right)-F(\beta, \tau)\right. \\
\left.-F\left(\beta e^{k M}, 0\right)+F(\beta, 0)\right]
\end{array}
$$


Table 2. Summary of Rossby wave features compared to previous studies. Extracted wavelengths and speeds are representative of the North Atlantic basin (mainly between $10^{\circ} \mathrm{N}$ and $40^{\circ} \mathrm{N}$ ) except for the Cipollini et al. (1997) study based on the North-East Atlantic at $34^{\circ} \mathrm{N}$.

\begin{tabular}{ccccl}
\hline $\begin{array}{c}\text { Amplitude } \\
(\mathrm{cm})\end{array}$ & $\begin{array}{c}\text { Wavelengths } \lambda \\
(\mathrm{km})\end{array}$ & $\begin{array}{c}\text { Phase Speeds } c_{\varphi} \\
\left(\mathrm{cm} \mathrm{s}^{-1}\right)\end{array}$ & Time period & \\
\hline $0-5$ & $400-1200$ & $3-4$ & 1998 & Present Study (MNATL) \\
$1-10$ & $500-1000$ & $2-8$ & $1993-2001$ & Charria et al. (2006a) \\
$0-7$ & $400-900$ & $2-8$ & $1997-2002$ & Killworth et al. (2004) \\
& $200-2000$ & $3-17$ & $1991-1996$ & Hill et al. (2000) \\
& $390-520$ & $0.9-3$ & $1992-1995$ & Cipollini et al. (1997) \\
$1.5-11.6$ & $400-4600$ & $1.2-31.25$ & $1992-1995$ & Polito and Cornillon (1997) \\
\hline
\end{tabular}

where $M$ is the mixed layer depth, $k=0.04 \mathrm{~m}^{-1}$ the light attenuation coefficient, $\beta=\left(J_{\max } \tau\right) /\left(\alpha I_{\text {noon }}\right)$ where $I_{\text {noon }}$ is the light level at the surface at noon, $\tau=d / 2$ the local time from sunrise to noon with $d$ the local duration of the day, and

$F\left(y, t^{\prime}\right)=\left(y^{2}+t^{\prime 2}\right)^{1 / 2}-t^{\prime} * \ln \frac{t+\left(y^{2}+t^{\prime 2}\right)^{1 / 2}}{y}$

$G(\mathrm{P})$ represents the zooplankton grazing, it is written following a Holling type III function:

$G(\mathrm{P})=\frac{g p \mathrm{P}^{2}}{g+p \mathrm{P}^{2}}$

with $g$, the maximum grazing rate for the high $\mathrm{P}$ values and $p$ the prey capture rate. The advection scheme is MUSCL (Monotonic Upstream centred Scheme for Conservation Laws - Lévy et al., 2001). This scheme is monotonic, positive with an implicit diffusion and a weak dispersion.

The interannual simulation has been initiated from Reynaud et al. (1998) climatology with a one year spin-up of the physical model in 1995. The coupled experiment started in 1996.

The initial dissolved inorganic nitrogen field is from the Conkright et al. (2002) climatology. The other biogeochemical variables need a shorter period to reach a balanced state (in order of one year). Consequently, the initial Phytoplankton, Zooplankton, and Dissolved Organic Nitrogen are respectively $0.14 \mathrm{mmolN} \mathrm{m}^{-3}, 0.014 \mathrm{mmolN} \mathrm{m}^{-3}$ and $3 \mathrm{mmolN} \mathrm{m}^{-3}$ at surface and are decreasing exponentially with depth. Detritus are initialized to $10^{-4} \mathrm{mmolN} \mathrm{m}^{-3}$ on the whole domain. An approximately stable seasonal cycle was reached after 2 years, end of 1997. The fields used in this study represent the third year of coupled integration (i.e. 1998). Statistical analyses and comparisons with remotely sensed and in situ data showed that the model reproduces well the seasonal cycle of the ecosystem as well as the primary production in the North Atlantic biogeochemical provinces (Charria et al., 2006b, 2008). However a few biases were highlighted in the simulated fields. The Gulf Stream position is too far North as compared to observations. This is a well known bias in this kind of general circulation model (Barnier et al., 2006). Concerning the biogeochemical fields, the northern boundary of the oligotrophic gyre is located too far South. Indeed, the northern boundary is located around $28^{\circ} \mathrm{N}$ in the observations and around $23^{\circ} \mathrm{N}$ in the simulated fields. The elevated chlorophyll concentrations in the oligotrophic gyre are linked to high inorganic nitrogen contents due to a fast remineralization loop above the nitracline associated with regenerated production.

\section{Data}

\subsection{Chlorophyll- $a$ concentrations}

Chlorophyll- $a$ concentrations (in $\mathrm{mgChl} \mathrm{m}^{-3}$ ) were obtained from the ocean colour sensor SeaWiFS (Sea-viewing Wide Field-of-view Sensor) products (level 3 binned data, monthly, version 4 - O'Reilly et al., 1998) generated by the NASA Goddard Space Flight Center (GSFC) Distributed Active Archive Center (DAAC) (McClain et al., 1998). The products are on a regular grid of 9 by $9 \mathrm{~km}$ for the year 1998 (similar to the simulated year). The predicted error on the single 1-km SeaWiFS estimates of chlorophyll- $a$ concentration is 35\% (McClain et al., 1998); the accuracy of $9 \mathrm{~km}$ gridded data is comparable or better. As our study focuses on the anomalies of surface chlorophyll- $a$ concentrations, a monthly zonal average from raw data at each latitude and for each month is removed (coastal regions are excluded), so also removing part of the seasonal cycle. To apply the spectral analysis and filtering described below, gaps in the data, mainly due to the presence of clouds, are filled with a linear interpolation.

\subsection{Sea Level Anomalies (SLA)}

Sea Level Anomaly data are provided by CLS Space Oceanography Division as part of the Environment and Climate EC AGORA and DUACS projects. These SLA were obtained from the combined processing of the Topex/Poseidon (T/P) and ERS-1/2 data. The two data sets were combined using an improved space/time objective analysis method taking into account long-wavelength-errors 


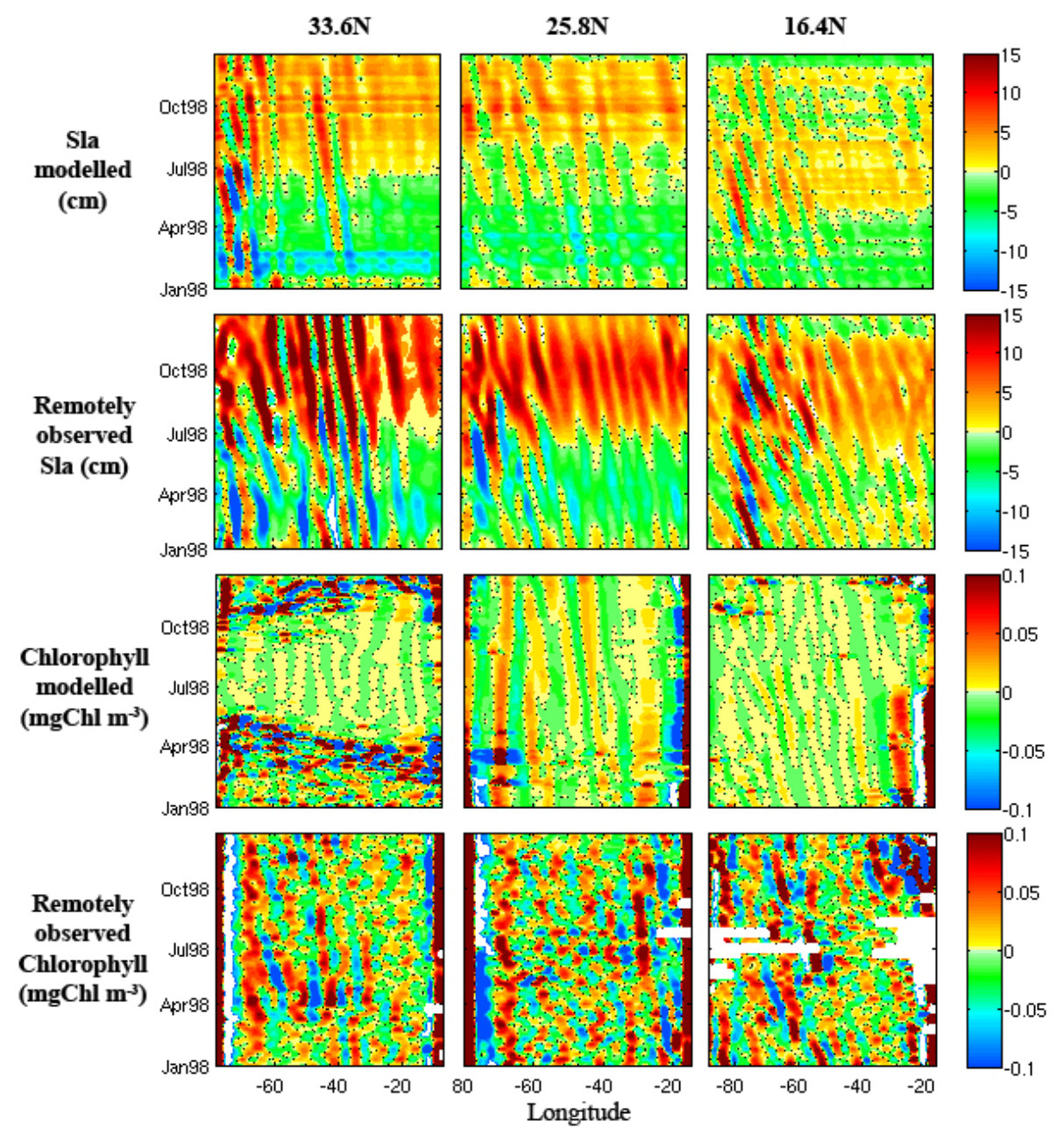

Fig. 2. Examples of longitude-time plots of simulated and remotely observed Sea Level Anomalies and surface chlorophyll concentrations for the $33.6^{\circ} \mathrm{N}, 25.8^{\circ} \mathrm{N}$, and $16.4^{\circ} \mathrm{N}$ latitudes after filtering with spatial 1-D wavelet analysis.

(noise correlated on large scales) with a $1-2 \mathrm{~cm}$ mean error (Le Traon et al., 1998; Ducet et al., 2000). SLA are relative to a seven year average (1993-1999) and were mapped every 7 days for the year 1998 with a spatial resolution of $1 / 3^{\circ}$. To have the same temporal resolution as for the surface chlorophyll- $a$ concentrations, SLA data were averaged with a monthly time step.

\section{Rossby waves in the coupled model}

Rossby wave features in the coupled experiment results (Sea Level Anomalies - SLA - and surface chlorophyll concentrations) are first described and compared to those deduced from remotely sensed data (Charria et al., 2006a).

The SLA are analysed to detect the westward propagating signals. The physical model does not have a free surface, so the effective SLA are calculated from the temperature and salinity fields and from the barotropic stream function com- puted with the pressure compensation relation (Mellor and Wang, 1996).

We will consider four main parameters (wavelength, amplitude, phase speed and phase relationship between SLA and surface chlorophyll concentrations) previously used in analysis of Rossby wave features.

The predominant wavelengths in SLA are calculated using a 1-D continuous wavelet analysis (Torrence and Compo, 1998) applied for each model latitude between $10^{\circ} \mathrm{N}$ and $40^{\circ} \mathrm{N}$. Maxima in the local wavelet power spectra are associated with wavelengths mainly located between 400 and $1000 \mathrm{~km}$ with a few occasions over $1000 \mathrm{~km}$. They are representative of the first baroclinic mode of Rossby waves according to the linear and extended theories (Killworth and Blundell, 2003). These values are similar to those estimated from remotely sensed data with Fourier-based spectral analyses (Cipollini et al., 1997; Hill et al., 2000; Killworth et al., 2004), least-square based analysis combined with Radon 

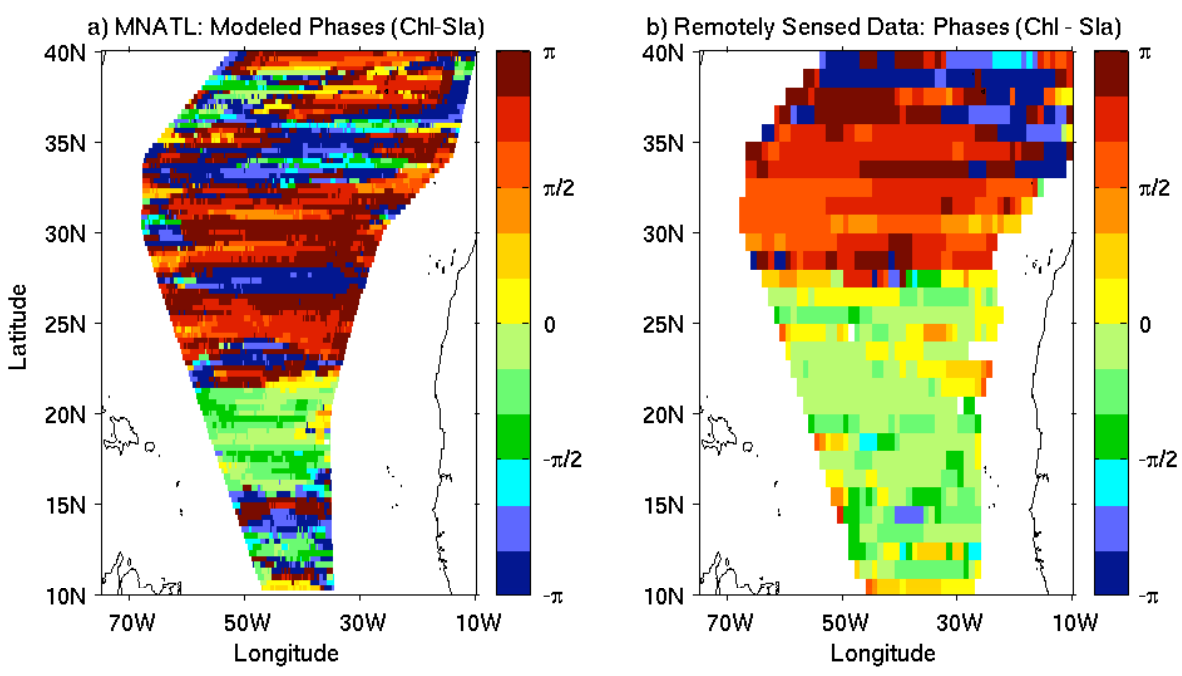

Fig. 3. Spatial phase relationships for the year 1998 between chlorophyll concentrations and SLA, averaged in time, obtained from a cross wavelet analysis for: the coupled model (a) and remotely sensed data (b).

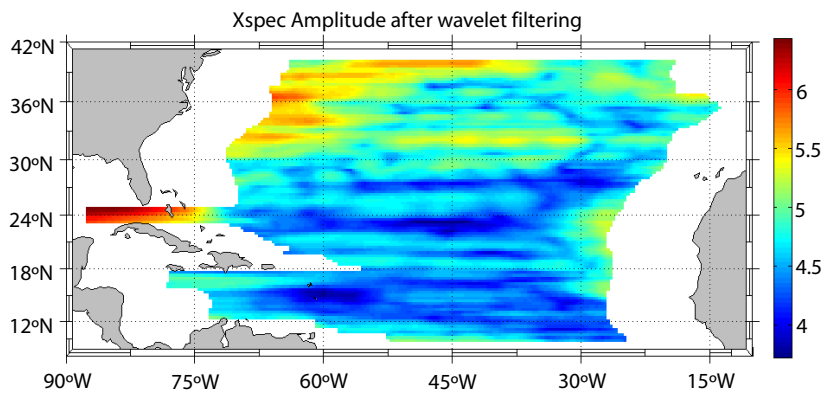

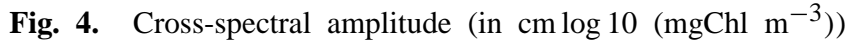
integrated over Rossby wave period and wavelength (3-24 months/400-1200 km) for 11 July 1998.

transform (Polito and Cornillon, 1997) or wavelet method (Charria, 2005; Charria et al., 2006a) (Table 2).

The modelled SLA are filtered reconstructing the signal for the wavelengths located between 400 and $1200 \mathrm{~km}$ after a 1-D continuous spatial wavelet analysis. To estimate the Rossby wave amplitude, the westward propagating signals are extracted (Fig. 2). The simulated waves present amplitudes weaker (reaching $5 \mathrm{~cm}$ ) than those observed $(7-10 \mathrm{~cm}$ ) in remotely sensed data (Killworth et al., 2004; Charria et al., 2006a) over the North Atlantic Ocean (Table 2). These lower amplitudes in the simulations are partly due to the model spatial resolution. With the 1/3-degree spatial resolution, our model results either do not include, or include with some smoothing, the effect of shorter-scale Rossby waves (less than $\sim 300 \mathrm{~km}$ ) as well as wave-eddy interactions. These processes are included in the satellite data and might explain the higher SLA amplitude in the satellite data. Another expla- nation is due to the atmospheric forcing (model input in our study), which might not have the right frequency (here daily) to force the entire Rossby wave spectrum as in the satellite data.

Propagation velocities (or phase speeds) associated with Rossby waves are calculated from the filtered time/longitude diagrams with a 2-D Radon transform method (Challenor et al., 2001). The modelled velocity values are between 3 and $4 \mathrm{~cm} \mathrm{~s}^{-1}$ (Table 2). They fall in the same range as those estimated in previous studies (Table 2). However, a narrower interval is observed for the present study partly due to the time period over which the phase speeds are estimated (Challenor et al., 2001).

Similar analyses, based on the longitude/time diagrams and using the same wavelet filter, are performed on the simulated surface chlorophyll concentration fields. A variable chlorophyll-to-nitrogen ratio was used following Hurtt and Armstrong (1996) to convert modelled phytoplankton in nitrogen units into chlorophyll concentrations. Wavelengths between 400 and $1500 \mathrm{~km}$ are observed in agreement with those deduced from the SeaWiFS data for the same year. Concerning the amplitudes associated with westward propagations, they are similar in the filtered modelled concentrations and in the filtered remotely sensed concentrations estimated by the SeaWiFS sensor. Note that chlorophyll anomalies are used, not absolute values; areas of high absolute chlorophyll concentrations may not necessarily show large anomalies.

Now we will examine the relationships between SLA and surface chlorophyll concentrations. Following Killworth et al.'s (2004) approach, the coupled processes involved can be estimated from the relationships between SLA and surface chlorophyll concentrations. As shown 

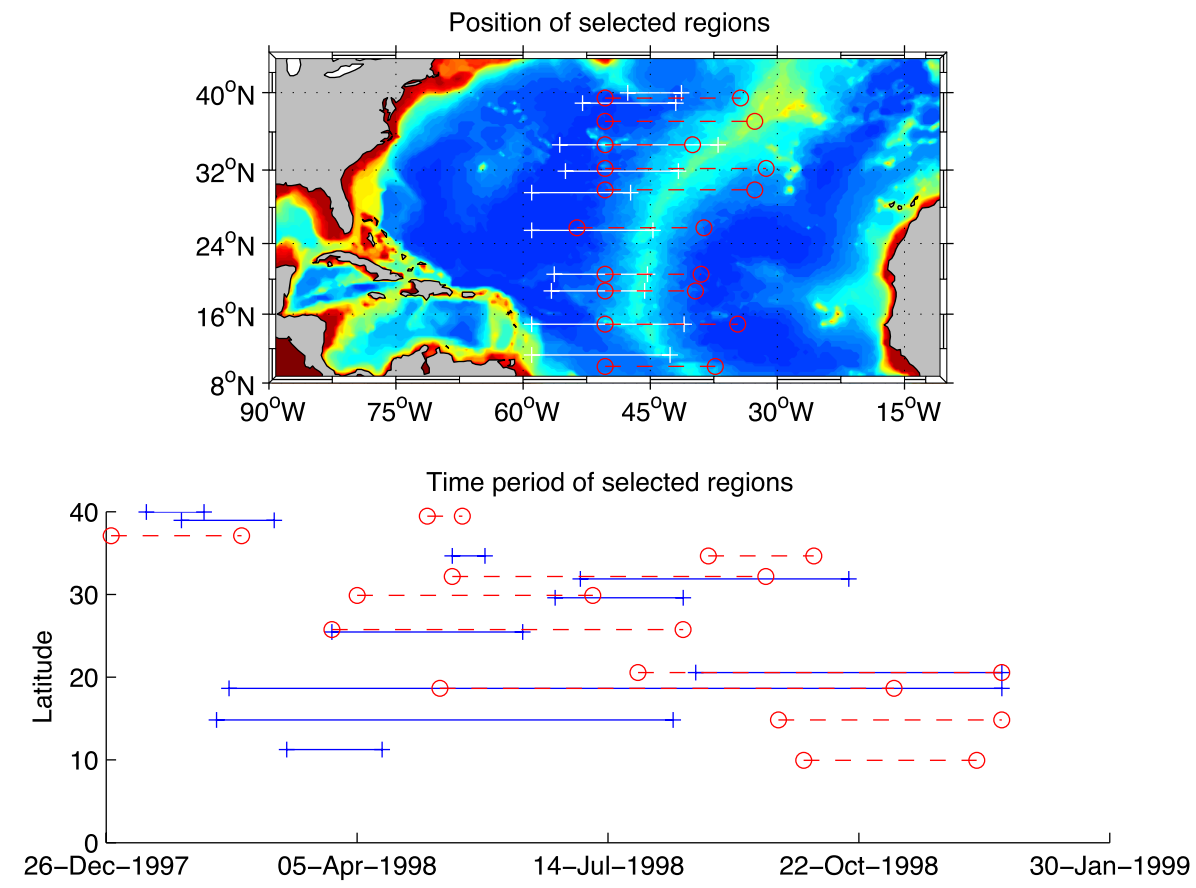

Fig. 5. Position (white lines and red lines) of selected regions compared to the model bathymetry (top) and time extension of these regions (bottom). Different colours are only used to distinguish regions around close latitudes and are similar in top and bottom figures.

by Charria et al. (2006a), the phase relationships between Rossby waves (signal in SLA) and their chlorophyll signature can be highly variable. We compare the phase relationships using a cross-wavelet analysis between filtered SLA and filtered surface chlorophyll concentrations. From $23^{\circ} \mathrm{N}$ to $35^{\circ} \mathrm{N}$, the modelled phase relationships (phase(Chlorophyll) - phase(SLA)) are mainly between $\pi / 2$ and $\pi$ (Fig. 3a). By contrast, between $16^{\circ} \mathrm{N}$ and $23^{\circ} \mathrm{N}$ in the simulated fields (Fig. 3a) and between $10^{\circ} \mathrm{N}$ and $28^{\circ} \mathrm{N}$ in the remotely sensed data (Fig. 3b), values of phase relationship are between $-\pi / 2$ and 0 . According to the theoretical approach from Killworth et al. (2004), we can deduce that between $16^{\circ} \mathrm{N}$ and $23^{\circ} \mathrm{N}$ in the simulations (between $10^{\circ} \mathrm{N}$ and $28^{\circ} \mathrm{N}$ in the data), the meridional chlorophyll advection should be the dominant process as confirmed by Charria et al. (2006a). However, the phase relationships deduced from the modelled fields north of $23^{\circ} \mathrm{N}$ do not allow to detect a clear dominant process when the meridional chlorophyll gradients are positive due to the same phase relationship for vertical and horizontal processes (Killworth et al., 2004).

After the analysis of modelled Rossby waves and chlorophyll signature features and the comparison with previous studies, we can conclude that Rossby waves are well represented in the model despite a southwards shift of the boundary between two different phase regimes due to modelled biogeochemical conditions.

\section{Region selection with significant Rossby wave signa- tures}

To quantify the influence of Rossby waves on primary production, our analysis is focused on the three parts of the wave chlorophyll signature: the positive chlorophyll anomaly linked to the wave's crest (hereafter $\mathrm{CA}+$ ), the negative anomaly linked to the wave's trough $(\mathrm{CA}-)$ and the lack of chlorophyll anomaly (CA0). The accurate identification of these wave patterns in particular regions needs the following pre-processing on the simulated fields.

Before extracting any wave, the previously spatially filtered fields (see Sect. 4) at each time step and each latitude are used to detect clear wave propagations in SLA and surface chlorophyll concentrations. A cross-spectrum analysis between SLA and the decimal logarithm of surface chlorophyll concentrations (similar to the analysis applied on remotely sensed data in Killworth et al., 2004) is then performed on longitude/time windows. Windows are 60 grid points wide (around $20^{\circ}$ in longitude). The cross-spectrum energy is integrated over Rossby wave period and wavelength (3-24 months/400-1200 km). Figure 4 shows the amplitude of the integrated cross-spectrum peak. Larger values are observed in the north-west part of the domain where Rossby waves have larger amplitudes. Then, several maxima can be extracted for different latitudes. We decided to focus on regions centred around the mid-Atlantic ridge and not influenced by the coastal effects. A few latitudes are then 


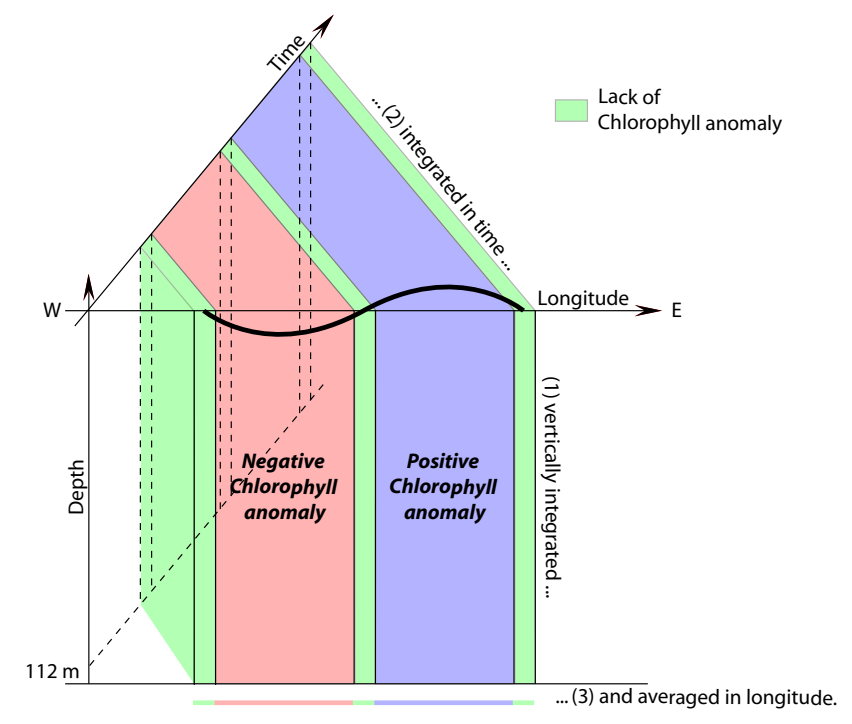

Fig. 6. Description of the integration method along the chlorophyll anomalies (CA+, $\mathrm{CA}-$ and $\mathrm{CA} 0)$.

selected between $30^{\circ} \mathrm{W}$ and $60^{\circ} \mathrm{W}$ where the cross-spectrum amplitudes are above $4.35 \mathrm{~cm} \log 10\left(\mathrm{mgChl} \mathrm{m}^{-3}\right)$. These peaks in the cross-spectrum correspond to different phase relationships between the surface chlorophyll anomalies and SLA. An homogeneous zonal distribution is also preferred. Based on these latitudes, the extent of the time/space region is refined over the time period where positive/negative chlorophyll anomalies can be clearly identified and followed in time. Indeed, the variations of the biogeochemical background conditions along the wave trajectory, tracked using the SLA signature, are inducing fluctuations in the chlorophyll signature intensity. Finally, 20 time/space regions are chosen over the basin (Fig. 5). These regions are equally distributed to cover different latitudes where propagations are well correlated with their chlorophyll signature.

For each area, we explain in detail dissolved inorganic nitrogen and phytoplankton modelled source and sink terms, as well as associated advective and diffusive terms, calculated at each time step during the model integration. Each quantity is vertically integrated over $112 \mathrm{~m}$ depth. Values obtained are then averaged in longitude over the positive or the negative chlorophyll anomalies. The value for the lack of chlorophyll anomaly (case CA0) is estimated from an average of values from the western boundary of the chlorophyll trough, between the chlorophyll crest and the chlorophyll trough and from the eastern boundary of the chlorophyll crest. The three integrated and averaged values (for $\mathrm{CA}-, \mathrm{CA} 0$ and $\mathrm{CA}+$ ) are then integrated over the time period (Fig. 6). The integrated terms (biogeochemical, advection and diffusion in mmolN m${ }^{-2}$ ) are then obtained for each region over the chlorophyll signature of the wave crest $(\mathrm{CA}+)$, the wave trough $(\mathrm{CA}-)$ and for assumed background conditions (CA0).

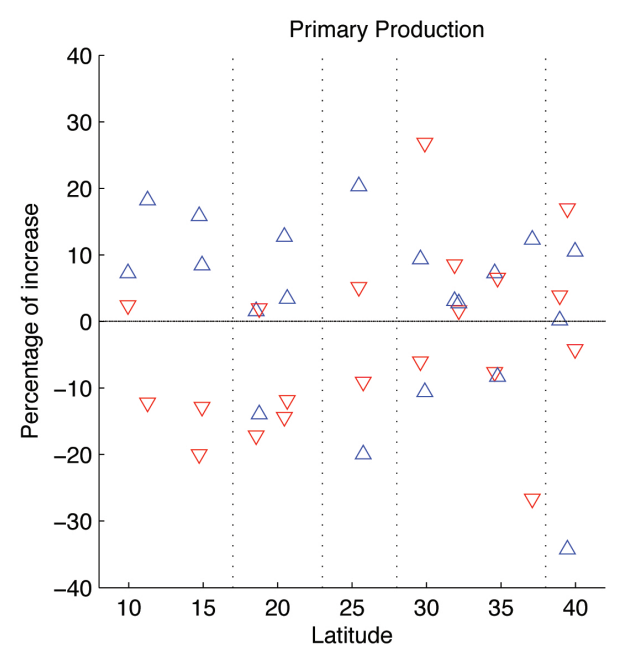

Fig. 7. Primary production increases (in $\%$ ) following the latitude over the positive $(\mathrm{CA}+$, blue $\triangle)$ and the negative $(\mathrm{CA}-$, red $\nabla)$ chlorophyll anomalies. Quantities are integrated over the time period, $112 \mathrm{~m}$ depth and averaged in longitude. The percentage of increase is derived from the value for the lack of chlorophyll anomaly. Vertical dotted lines are limiting the regions described in the text.

\section{Results}

Two kinds of terms are then extracted: the biological fluxes between the ecosystem components and the physical advection/diffusion terms. To understand the origin of higher chlorophyll concentrations due to the wave's passage, the horizontal and vertical advection terms as well as the vertical diffusion are analysed (the MUSCL advection scheme does not resolve any horizontal diffusion).

\subsection{Chlorophyll wave crest and primary production}

First, the terms for the chlorophyll signature of the wave crest $(\mathrm{CA}+)$ are analysed. The influence on primary production is obtained for each region (Fig. 7) and then the underlying physical processes investigated (Figs. 8-10). Indeed, the primary production, which is nutrient-limited between $8^{\circ} \mathrm{N}$ and $40^{\circ} \mathrm{N}$, is function of dissolved inorganic nitrogen and phytoplankton concentrations (Eq. 2). Results are very sensitive to the latitude and the time period considered. Nevertheless, we can consider five main subgroups for different zonal bands.

In the northern part of the domain, north of $39^{\circ} \mathrm{N}$, two main regions are considered ${ }^{1}$ :

- Region 1: $40^{\circ} \mathrm{N}-41.3^{\circ} \mathrm{W}$

- Region 2: $39.5^{\circ} \mathrm{N}-34.3^{\circ} \mathrm{W}$

A $+10.5 \%$ increase $^{2}$ in primary production is obtained

\footnotetext{
${ }^{1}$ Regions are identified using the latitude and the easternmost position of the wave during the given period.

${ }^{2}$ The percentage of increase (or decrease) is the difference between $\mathrm{CA}+($ or $\mathrm{CA}-$ ) and $\mathrm{CA} 0$ divided by the absolute
} 

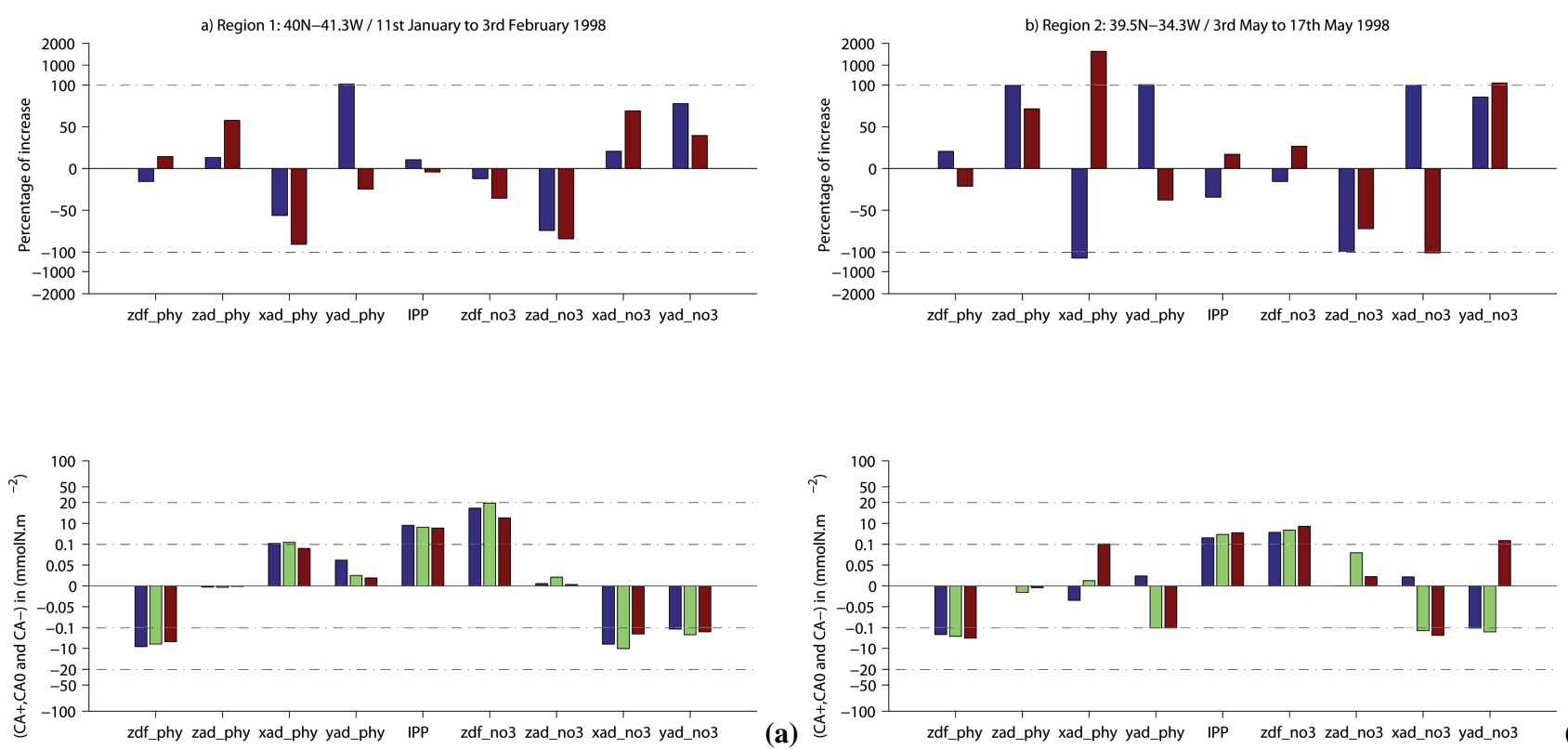

(b)

Fig. 8. Meridional (yad), zonal (xad) and vertical (zad) advection of phytoplankton (phy) and dissolved inorganic nitrogen (no3), vertical diffusion of phytoplankton (zdf_phy) and inorganic nitrogen (zdf_no3) and primary production (IPP) at $40^{\circ} \mathrm{N}-41.3^{\circ} \mathrm{W}$ (Region 1 ) from 11 January to 3 February 1998 (a) and $39.5^{\circ} \mathrm{N}-34.3^{\circ} \mathrm{W}$ (Region 2) from 3 May to 17 May 1998 (b). The coordinates used to identify the regions are the latitude and the easternmost position of the wave during the given period. These quantities are integrated over the time period, $112 \mathrm{~m}$ depth and averaged in longitude over the positive (blue) and the negative (red) chlorophyll anomalies. The percentage of increase (top) is derived from the value for the lack of chlorophyll anomaly. The bottom figure represents the total values in mmolN $\mathrm{m}^{-2}$ of the integrated fluxes over the positive (blue), the negative (red) anomalies, and the background condition (green). The Y-axis is divided in five intervals: $[-100-20],[-20-0.1],[-0.10 .1],[0.120]$, and [20 100].

for the northernmost latitude (Region 1). This value can be associated with the meridional advection processes (dissolved inorganic nitrogen and phytoplankton). Indeed, the phytoplankton meridional advection and the inorganic nitrogen meridional advection are reaching respectively more than $+140 \%\left(3.6 \times 10^{-2} \mathrm{mmolN} \mathrm{m}^{-2}\right)$ and $+78 \%\left(2.71 \mathrm{mmolN} \mathrm{m}^{-2}\right)$ of the CA0 condition, respectively (Fig. 8a). Figure 9 highlights the largest dissolved inorganic nitrogen concentration along the chlorophyll signature of the wave crest $(\mathrm{CA}+)$ compared to the mean background condition. At the opposite, a strong decrease in primary production $(-34.3 \%)$ can be noticed in the southernmost latitude $\left(39.5^{\circ} \mathrm{N}-34.3^{\circ} \mathrm{W}\right)$ (Fig. 8b). This decreasing production is mainly explained by a strong diminution of the vertical inorganic nitrogen advection $\left(-7.9 \times 10^{-2} \mathrm{mmolN} \mathrm{m}^{-2}\right)$ and diffusion $\left(-1.06 \mathrm{mmolN} \mathrm{m}^{-2}\right)$. The $\mathrm{CA}+$ is then mainly explained by an increase of meridional phytoplankton advection and vertical phytoplankton diffusion (Fig. 8b). These first results illustrate the complex variability in the Rossby wave influence on primary production. Furthermore, these two close latitudes are corresponding to very different time periods (winter in Region 1 and spring in Region

value of CA0 and multiplied by 100 : for instance (100[(CA+)$\mathrm{CA} 0] /|\mathrm{CA} 0|$ ).
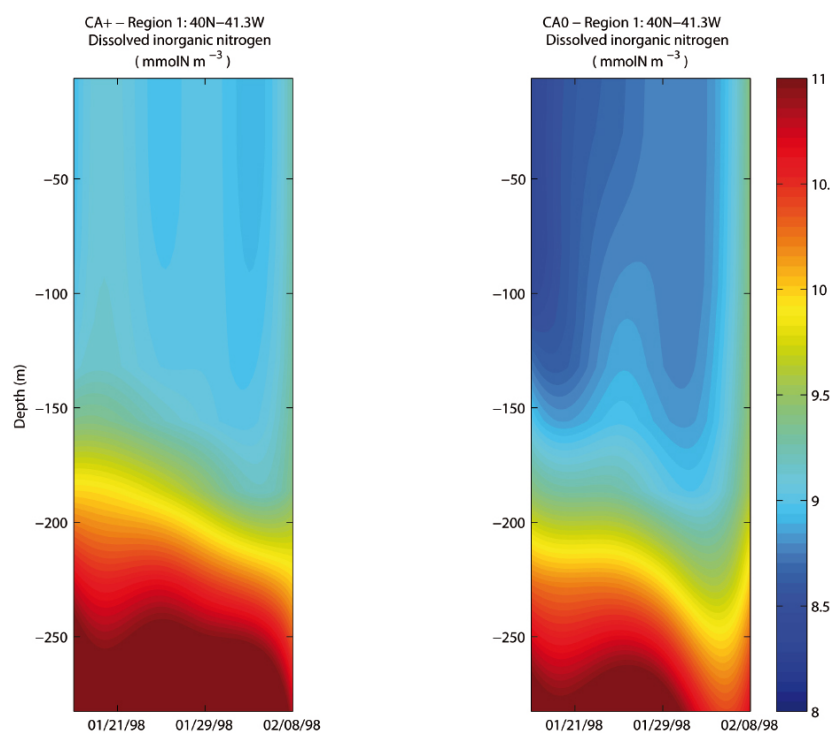

Fig. 9. Vertical dissolved inorganic nitrogen distribution along the chlorophyll signature of the wave crest $(\mathrm{CA}+)$ and $\mathrm{CA} 0$ for the region $40^{\circ} \mathrm{N}-41.3^{\circ} \mathrm{W}$ (Region 1). 

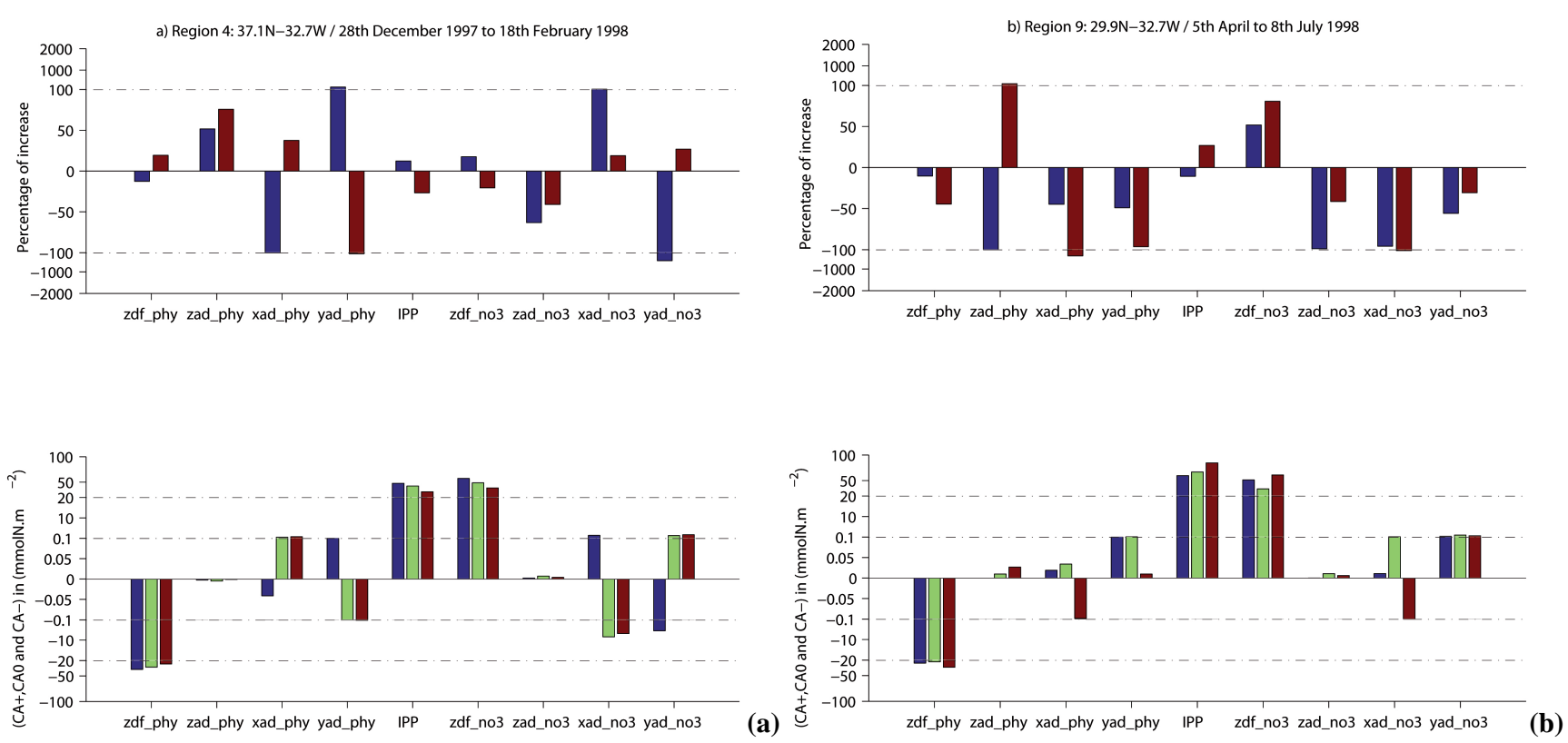

Fig. 10. Same quantities as represented in Fig. 8 at $37.1^{\circ} \mathrm{N}-32.7^{\circ} \mathrm{W}$ (Region 4) from 28 December 1997 to 18 February 1998 (a) and $29.9^{\circ} \mathrm{N}-32.7^{\circ} \mathrm{W}$ (Region 9) from 5 April to 8 July 1998 (b).

2) associated with two different biogeochemical regimes (bloom in spring). In spring, the primary production associated with the CA+ will then decrease due to the limiting effect of the vertical inorganic nitrogen advection. The combination of these different factors linked to biogeochemical background and Rossby wave features can easily explain such a difference between these two situations.

Further south, eight extracted regions between 29 and $39^{\circ} \mathrm{N}$ are considered together ${ }^{1}$ :

- Region 3: $38.9^{\circ} \mathrm{N}-42^{\circ} \mathrm{W}-+0.2 \%$

- Region 4: $37.1^{\circ} \mathrm{N}-32.7^{\circ} \mathrm{W}-+12.3 \%$

- Region 5: $34.7^{\circ} \mathrm{N}-37^{\circ} \mathrm{W}-+7.2 \%$

- Region 6: $34.7^{\circ} \mathrm{N}-40^{\circ} \mathrm{W}--8.3 \%$

- Region 7: $32.2^{\circ} \mathrm{N}-31.3^{\circ} \mathrm{W}-+2.7 \%$

- Region 8: $31.9^{\circ} \mathrm{N}-41.7^{\circ} \mathrm{W}-+3.1 \%$

- Region 9: $29.9^{\circ} \mathrm{N}-32.7^{\circ} \mathrm{W}--10.6 \%$

- Region 10: $29.6^{\circ} \mathrm{N}-47.3^{\circ} \mathrm{W}-+9.4 \%$

In this band, primary production is slightly increasing between CA0 and CA+ except for the Region 6 and Region 9 where the primary production is decreasing $(-8.3 \%$ and $-10.6 \%$ respectively). For these different cases, the primary production increase is mainly driven by the horizontal advection and vertical diffusion of phytoplankton and dissolved inorganic nitrogen. The vertical advection is also playing a role but the nitrogen concentrations upwelled are weak (less than $8 \times 10^{-3} \mathrm{mmolN} \mathrm{m}^{-2}$ ) compared to the diffusion (larger than $1.2 \mathrm{mmolN} \mathrm{m}^{-2}$ ). For example, in Fig. 10a (Region 4), the CA+ is associated with a strong enhancement of the meridional phytoplankton advection. By contrast, in Fig. 10b, we observe that the primary production diminution is due to decreases in horizontal phytoplankton and inorganic nitrogen advection $\left(-0.13 \mathrm{mmolN} \mathrm{m}^{-2}\right.$ and $\left.-0.57 \mathrm{mmolN} \mathrm{m}^{-2}\right)$. Decreases in vertical advection are weaker $\left(-9.36 \times 10^{-3} \mathrm{mmolN} \mathrm{m}^{-2}\right.$ for phytoplankton and $-1 \times 10^{-2} \mathrm{mmolN} \mathrm{m}^{-2}$ for DIN).

Between $25^{\circ} \mathrm{N}$ and $26^{\circ} \mathrm{N}$, two wave signatures are followed for two very close latitudes:

- Region 11: $25.8^{\circ} \mathrm{N}-38.7^{\circ} \mathrm{W}$

- Region 12: $25.5^{\circ} \mathrm{N}-44.7^{\circ} \mathrm{W}$

and with a common initial time but for a longer time period in the case of the easternmost longitude (from $26 \mathrm{March}$ to 10 June in Region 12 and to 13 August in Region 11). Surprisingly, the effects of the wave passage on the primary production are completely different. For the easternmost region (Fig. 5), we observe a strong decrease in primary production associated with $\mathrm{CA}+(-19.9 \%)$ due to smaller dissolved inorganic concentrations (Fig. 11 - Region 11). At the other location, we found $a+20.3 \%$ augmentation related to an increase in dissolved inorganic nitrogen concentrations (Fig. 11 - Region 12). The source of the increase is associated with vertical and horizontal sources of dissolved inorganic nitrogen with a larger contribution from the vertical diffusion of dissolved inorganic nitrogen $\left(+3.33 \mathrm{mmolN} \mathrm{m}^{-2}\right)$.

Wave signatures are tracked for different time periods at $20.6^{\circ} \mathrm{N}$ and $18.7^{\circ} \mathrm{N}$ :

- Region 13: $20.6^{\circ} \mathrm{N}-45.3^{\circ} \mathrm{W}$

- Region 14: $20.6^{\circ} \mathrm{N}-39^{\circ} \mathrm{W}$

- Region 15: $18.7^{\circ} \mathrm{N}-45.7^{\circ} \mathrm{W}$

- Region 16: $18.7^{\circ} \mathrm{N}-39.7^{\circ} \mathrm{W}$ 

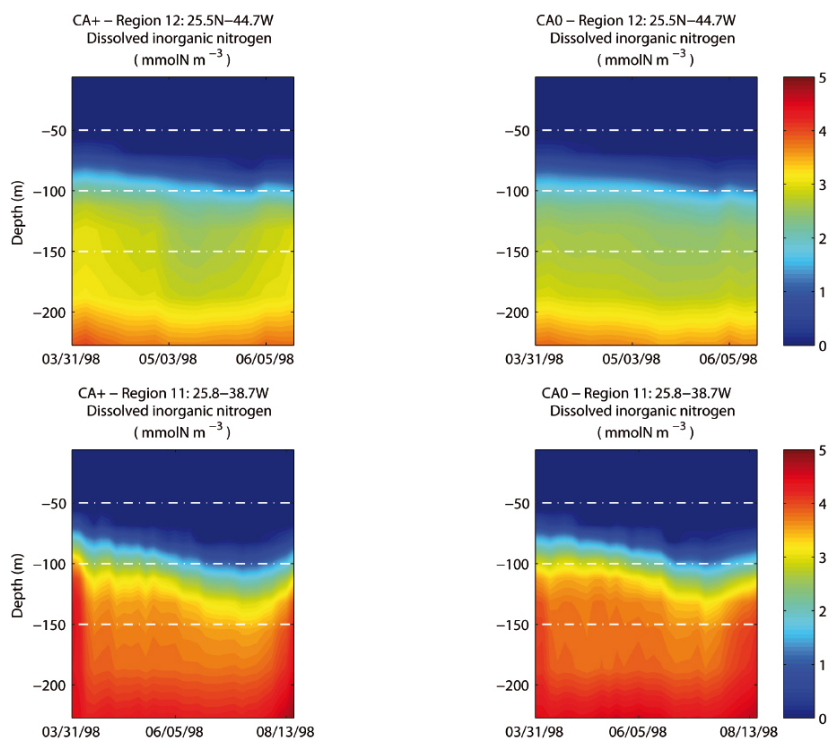

Fig. 11. Vertical dissolved inorganic nitrogen distribution along the chlorophyll signature of the wave crest $(\mathrm{CA}+)$ and $\mathrm{CA} 0$ for the region $25.5^{\circ} \mathrm{N}-44.7^{\circ} \mathrm{W}$ (Region 12 , top) and $25.8^{\circ} \mathrm{N}-38.7^{\circ} \mathrm{W}$ (Region 11 , bottom). White dashed lines represent the depths $50 \mathrm{~m}$, $100 \mathrm{~m}, 150 \mathrm{~m}$.

First, at $20.6^{\circ} \mathrm{N}$, primary production enhancements are observed. These are estimated at $+3.4 \%$ over a period (26 July to 18 December) and $+12.7 \%$ over a shorter time period (18 August to 18 December). The vertical diffusion of phytoplankton allows to explain this production increase. Indeed, vertical phytoplankton profiles show a subsurface maximum around $80 \mathrm{~m}$ depth more intense along the $\mathrm{CA}+$ (Fig. 12). The difference between these two values is associated with the integration time period and highlights a negative effect on primary production in the CA+ between mid-July and mid-August 1998 for this latitude. At $18.7^{\circ} \mathrm{N}, \mathrm{a}-13.9 \%$ decrease is obtained in the eastern part. This last decrease is associated with a diminution of the meridional advection and vertical diffusion of phytoplankton $\left(-0.17 \mathrm{mmolN} \mathrm{m}^{-2}\right.$ and $\left.-0.4 \mathrm{mmolN} \mathrm{m}^{-2}\right)$ and dissolved inorganic nitrogen $\left(-2.3 \times 10^{-2} \mathrm{mmolN} \mathrm{m}^{-2}\right.$ and $-2.9 \times 10^{-2} \mathrm{mmolN} \mathrm{m}^{-2}$ ) during the wave passage.

Finally in the southern part of the domain $\left(9^{\circ} \mathrm{N}-15^{\circ} \mathrm{N}\right)$, four extracted regions are considered:

- Region 17: $14.8^{\circ} \mathrm{N}-34.7^{\circ} \mathrm{W}-+15.8 \%$

- Region 18: $14.8^{\circ} \mathrm{N}-41^{\circ} \mathrm{W}-+8.4 \%$

- Region 19: $11.3^{\circ} \mathrm{N}-42.7^{\circ} \mathrm{W}-+18.2 \%$

- Region 20: $10^{\circ} \mathrm{N}-37.3^{\circ} \mathrm{W}-+7.3 \%$

The analysed wave signatures are initially tracked east of the mid-Atlantic Ridge Region 17 and Region 20) and over the Ridge (Region 18 and Region 19). The westernmost waves are observed earlier during the year than the easternmost propagations. In every case, an increase in primary produc-
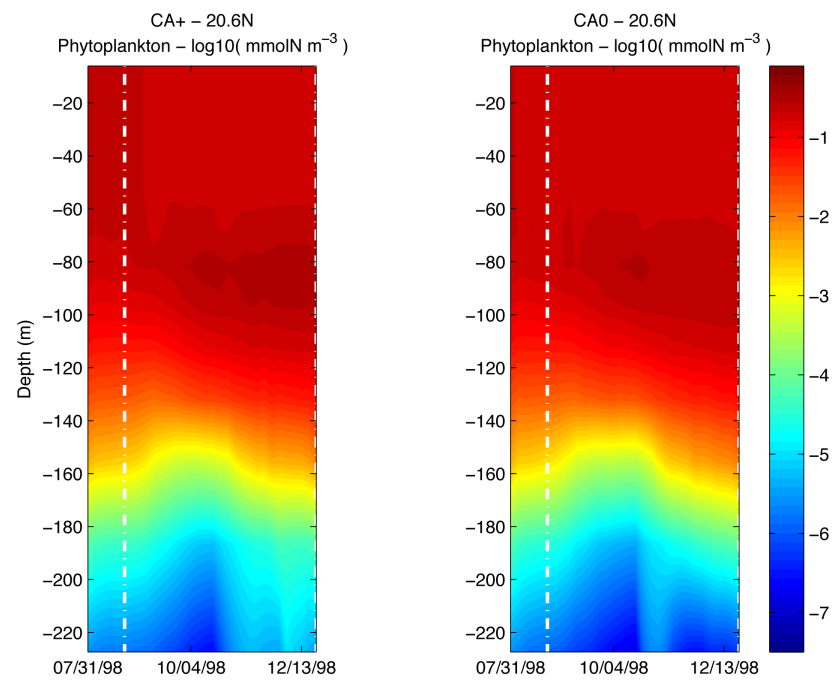

Fig. 12. Vertical phytoplankton distribution along $\mathrm{CA}+$ and $\mathrm{CA} 0$ for the two regions at $20.6^{\circ} \mathrm{N}$. White dashed lines mark the start of the shortest and westernmost region.

tion associated with $\mathrm{CA}+$ is noticed. It appears that wave signatures from the eastern part of the basin observed during autumn have a weaker impact on primary production than those observed in spring and summer. This is in agreement with a more stratified ocean in summer. Indeed, when we detail the processes involved, the vertical input of dissolved inorganic nitrogen explains the production increase (Fig. 13a). By contrast, during the less productive season, the primary production increase associated with the wave signature is due to meridional phytoplankton advection and vertical phytoplankton diffusion (Fig. 13b). There is no significant inorganic nitrogen advective input.

\subsection{Chlorophyll wave trough and primary production}

After analyzing the processes explaining the surface chlorophyll positive anomaly and the impact on the primary production, the opposite situation during the chlorophyll negative anomaly (CA-) is explored. It generally appears in the southern part of the domain that the CA- is associated with reduced primary production (Fig. 7). This first result confirms that the vertical advection of dissolved organic nitrogen or phytoplankton is never the only process involved during the wave's passage. This effect needs then to be offset by different mechanisms such as horizontal advection to explain the decrease in primary production measured as well as the negative surface chlorophyll anomaly.

Except in a few regions, the primary production trend (increase or decrease) in the CA- is then opposite to the situation in the CAt. This opposition is also observed when we consider each mechanism separately. 

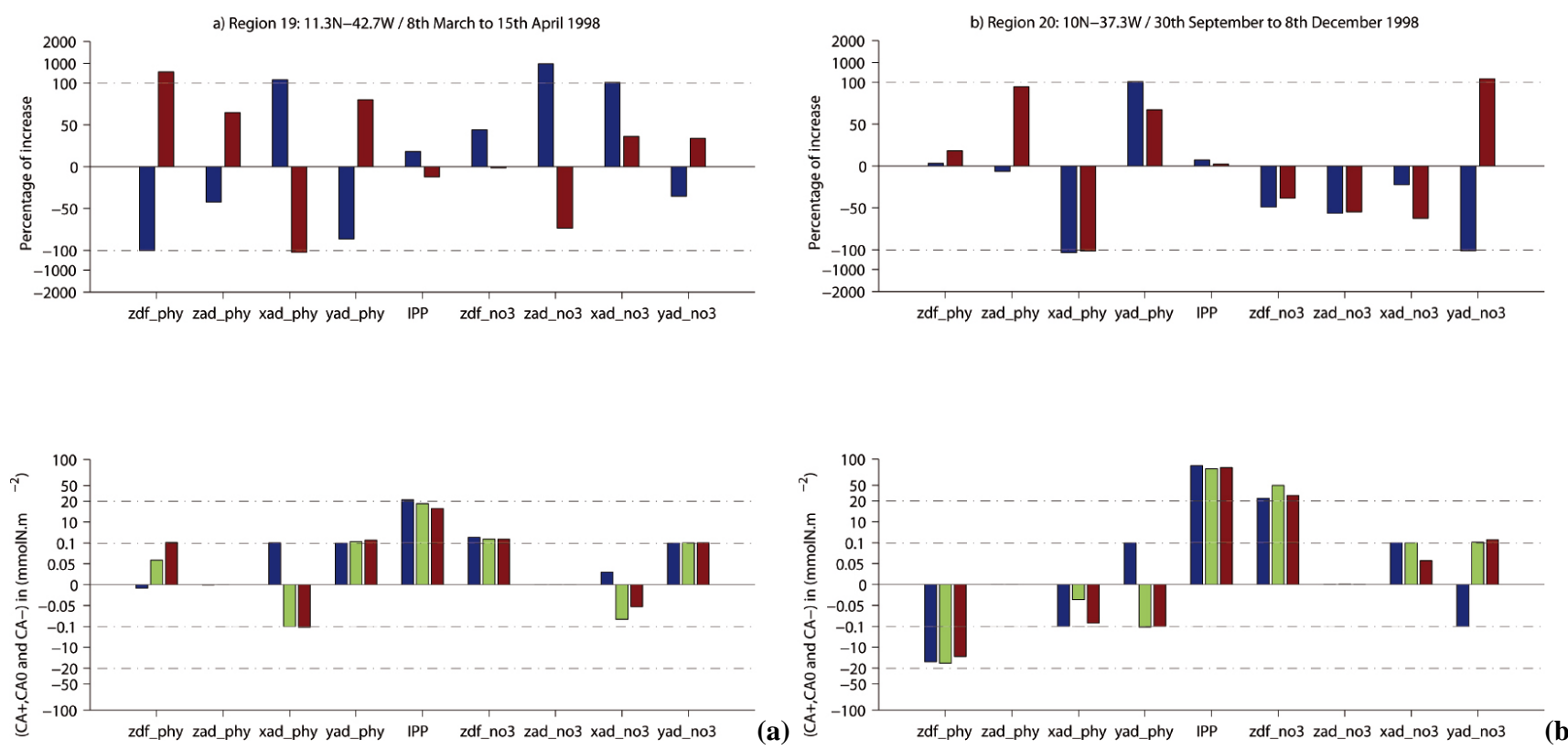

Fig. 13. Same quantities as represented in Fig. 8 at $11.3^{\circ} \mathrm{N}-42.7^{\circ} \mathrm{W}$ (Region 19) from 8 March to 15 April 1998 (a) and $10^{\circ} \mathrm{N}-37.3^{\circ} \mathrm{W}$ (Region 20) from 30 September to 8 December 1998 (b).

More surprisingly, we can remark that when the primary production is decreasing over the $\mathrm{CA}+$, the situation in the $\mathrm{CA}-$ is opposite and we generally observe an increase in primary production associated with the $\mathrm{CA}-$. This result suggests the important role of meridional advective mechanisms as suggested by Killworth et al. (2004) and Charria et al. (2006a). Indeed, in the case of an horizontal advection, the chlorophyll is similar to a passive tracer and only reacts to the physical forcing without significant changes in the biogeochemical processes. These purely physical processes are theoretically symmetrical between the crest and the trough of a Rossby wave. This bipolar system reflects a symmetric effect of the Rossby waves on primary production which suggests that the net effect of Rossby waves on primary production would be very small.

\section{Discussion}

In the present work, the different biogeochemical-physical mechanisms explaining the surface chlorophyll signature of Rossby waves are investigated through the exploration of the effect of these waves on primary production. The use of a realistic coupled physical/biogeochemical model in the North Atlantic allows to detail separately the positive and negative surface chlorophyll anomalies associated with these waves.

The biogeochemical advective and diffusive fluxes analysed for 20 areas highlight the fact that the increase of phytoplankton biomass in the CA+ is due to a complex combination of vertical and meridional processes depending on the considered latitude. This surface chlorophyll positive anomaly is associated with various patterns of primary production depending upon season and region (latitude and longitude). Previous studies with remotely sensed data and theoretical modelling from Killworth et al. (2004) and Charria et al. (2006a) showed that south of $28^{\circ} \mathrm{N}$ the Rossby wave signature in chlorophyll concentration can be mostly explained by the meridional chlorophyll advection. When we compare those results to the present work (Fig. 14), the role of the horizontal advection is also noticed but several regions highlight also a strong effect of the dissolved inorganic nitrogen vertical inputs by advection and diffusion. Based on the 20 present regions analysed, the different relative contributions north and south of $28^{\circ} \mathrm{N}$ (as described in Charria et al., 2006a) are not fully reproduced. This can be partly explained by the limited time period and the specific location of the selected regions. Furthermore, several assumptions had been made to compare remotely sensed data and theoretical modelling in Killworth et al. (2004) and Charria et al. (2006a). Indeed, a simple term had been used to represent the source and sinks biogeochemical terms in the theoretical model and several statistical assumptions had been made to fit the model outputs with observations. However, the present results of the realistic simulations confirm the weak contribution of the vertical advection and diffusion of chlorophyll, apparent in the whole domain (Fig. 14) except in one or two locations.

The second part of this work addresses the local impact of Rossby waves on primary production following the time period and location. When we quantify the local enhancement 
of primary production due to the wave passage, values between $-34.3 \%$ (latitude $39.5^{\circ} \mathrm{N}-34.3^{\circ} \mathrm{W}$ ) and $+20.3 \%$ (latitude $25.5^{\circ} \mathrm{N}-44.7^{\circ} \mathrm{W}$ ) in percentage of increase and between $-7.07 \mathrm{mmolN} \mathrm{m}^{-2}$ (latitude $29.9^{\circ} \mathrm{N}-32.7^{\circ} \mathrm{W}$ ) and +9.42 mmolN m$^{-2}$ (latitude $14.8^{\circ} \mathrm{N}-34.7^{\circ} \mathrm{W}$ ) are obtained. These values represent the difference between $\mathrm{CA}+$ and CA0 primary productions (divided by the $\mathrm{CA} 0$ primary production for the percentages). It appears that the relative increases are mainly sustained by vertical diffusion processes and horizontal advection. Furthermore, the vertical inputs of dissolved inorganic nitrogen seem to be systematically involved in spring and summer when the increases of primary production are exceeding 5\%. By contrast, decreases in primary production associated with the $\mathrm{CA}+$ are generally due to a decrease of the vertical advection and diffusion of dissolved inorganic nitrogen. For the other situations, the primary production decreases associated with $\mathrm{CA}+$ can be explained by a contribution of the meridional advection of phytoplankton. Kawamiya and Oschlies (2001), with the same kind of coupled physical/biogeochemical model applied in the Indian Ocean, showed that Rossby waves can induce a $\sim 30 \%$ increase of primary production associated with the uplifting of the deep chlorophyll maximum during the wave passage. In the Pacific, Sakamoto et al. (2004), based on local measurements at the ALOHA site and on an estimated relationship between primary production and Sea Surface Height anomalies estimated near the HOT station ALOHA, showed similar increases in primary production reaching $25 \%$. They were linked to nitrate injection in the euphotic layer during two well identified passages of Rossby waves. Using the same relationship, these authors conclude on a limited role of Rossby waves, which induce a mean primary production enhancement lower than 5-10\% over the 1997-1999 period. These values are also comparable to our estimations over the selected transects in the North Atlantic Ocean.

Consequently, our results suggest a net weak effect of Rossby waves on primary production.

These estimations need however to be considered carefully. These results using a realistic ocean general circulation model in the North Atlantic are obtained on a small set of zonal sections mainly located in low production provinces, and for a short time period. Furthermore, the method used to identify wave propagation in surface chlorophyll concentrations is based on several assumptions necessary to perform this first detailed analysis of the coupled physical/biogeochemical processes involved during the Rossby wave propagation. Another point that needs further investigation is whether the signal is due to Rossby waves, eddies or both. A recent study from Chelton et al. (2007) suggests that most westward propagating features observed in remotely sensed sea surface height are the signature of non linear propagating eddies. In the North Atlantic, more than $25 \%$ of the variance is explained by eddies instead of Rossby waves west of $53^{\circ} \mathrm{W}$ and north of $32^{\circ} \mathrm{N}$. In our studied domain, 14 out of 20 regions are located south of $32^{\circ} \mathrm{N}$ and
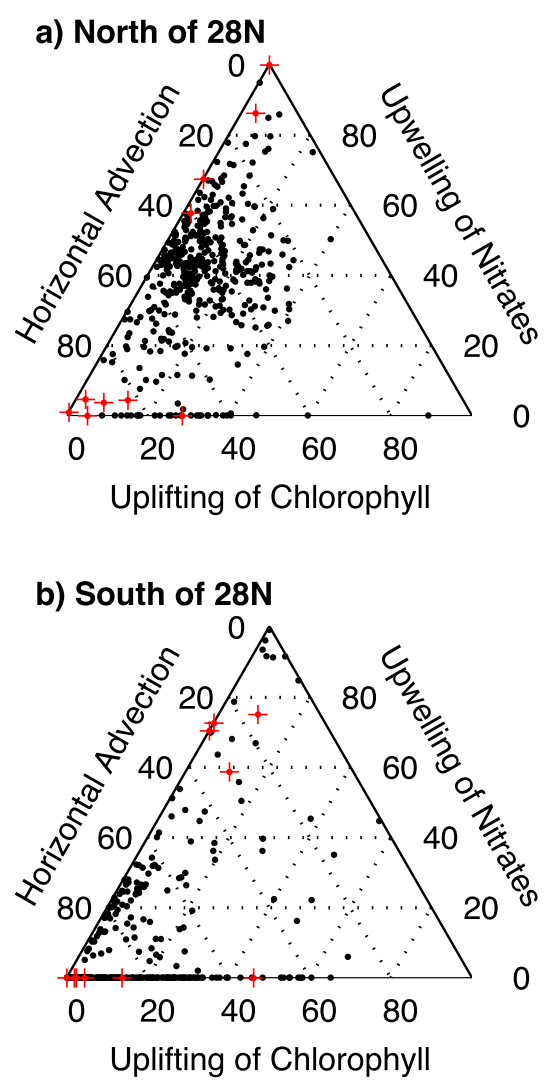

Fig. 14. Relative contribution (in \%) of the three processes which can explain the chlorophyll signature of Rossby waves: horizontal advection, upwelling of dissolved inorganic nitrogen in the euphotic zone and uplifting of the subsurface chlorophyll maximum. The black dots represent the results from Charria et al. (2006a) north of $28^{\circ} \mathrm{N}$ (a) and south of $28^{\circ} \mathrm{N}$ (b) between $9.5^{\circ} \mathrm{N}$ and $40.5^{\circ} \mathrm{N}$. The superimposed red crosses represent the 20 regions analysed in this study with the 3-D model outputs. The horizontal advection is the sum of the zonal and meridional chlorophyll and inorganic nitrogen advections. The upwelling of nitrates is the sum of vertical advection and diffusion for dissolved inorganic nitrogen. The uplifting of chlorophyll is the sum of vertical advection and diffusion for chlorophyll. The relative contributions are computed from the mechanisms associated with the chlorophyll wave crest in each region.

east of $53^{\circ} \mathrm{W}$ which is a region where non linear eddies are not predominant (Chelton et al., 2007). Furthermore, Isachsen et al. (2007) showed that, in a large ocean basin, baroclinic Rossby waves north of $30^{\circ} \mathrm{N}$ are unstable. North of $32^{\circ} \mathrm{N}$, it is therefore more likely that the signature observed in the data be due to eddies. However, Mouriño-Carballido and McGillicuddy (2006) showed that in the case of eddies, the primary production associated with the negative chlorophyll anomaly will be similar to the background primary production. In the present work, we showed that generally, the negative chlorophyll anomaly is associated with a decrease 
in primary production which suggests a wave-like process acting instead of non linear eddies.

\section{Conclusions}

Rossby waves, a process previously observed with remotely sensed data, were modelled using a 3-D coupled physical/biogeochemical model in the North Atlantic ocean. Waves are well reproduced as well as their signature in surface chlorophyll concentrations. The analysis based on 20 regions showed the important contribution of horizontal advection and of vertical inorganic dissolved nitrogen advection and diffusion. The main mechanism involved differs according to the biogeochemical conditions (due to latitude and time period). Furthermore, Rossby waves have a non negligible influence on primary production which can be quantified using coupled 3-D modelling. Indeed, positive surface chlorophyll anomalies are generally associated with an increase in primary production. This approach also allowed to explore the influence of chlorophyll troughs on primary production and a negative effect was observed. The net impact of Rossby waves on primary production, based on the 20 regions analysed, seems to be weak due to the symmetrical shape of the wave effects (between crest and trough). However, as suggested by Sakamoto et al. (2004), inputs of dissolved inorganic nitrogen can induce shifts in the phytoplankton community structure and consequently increase the exported production. This approach using a limited number of specific time-longitude cases needs to be extended to the whole basin in order to quantify the net basin scale effect of Rossby waves on primary production. To perform this estimation, we need to investigate what happens when the Rossby wave effect is removed. This calls for a more systematic study with coupled physical/biogeochemical models where Rossby waves can be switched on and off.

Acknowledgements. Financial support for this work was provided by the GMMC (Groupe Mission MERCATOR/CORIOLIS) to LEGOS (Toulouse, France). The physical model was provided by MERCATOR (http://www.mercator-ocean.fr). The calculations were conducted with the support of IDRIS/CNRS. The work was funded by CNES and IFREMER through a PhD fellowship, by the University Paul Sabatier through a postdoctoral fellowship and by the European Commission through a Marie-Curie postdoctoral fellowship (MEIF-CT-2006-039180). Wavelet software was provided by C. Torrence and G. Compo, and is available at http://paos.colorado.edu/research/wavelets/. We are grateful to B. Salihoglu, J. Sudre, M.-H. Radenac, and B. Mete Uz for their remarks and suggestions, J. Llido for his participation in the model validation as well as the three anonymous referees for their very fruitful and constructive comments on this manuscript.

Edited by: J. M. Huthnance

\section{References}

Barnier, B., Madec, G., Penduff, T., et al.: Impact of partial steps and momentum advection schemes in a global ocean circulation model at eddy-permitting resolution, Ocean Dynam., 56, 543567, 2006.

Challenor, P. G., Cipollini, P., and Cromwell, D.: Use of the 3D Radon Transform to Examine the Properties of Oceanic Rossby Waves, J. Atmos. Oceanic Tech., 18, 1558-1566, 2001, See also: Corrigendum: J. Atmos. Oceanic Tech., 19, 828, 2002.

Charria, G., Mélin, F., Dadou, I., Radenac, M. H., and Garçon, V.: Rossby wave and ocean colour: The cells uplifting hypothesis in the South Atlantic Subtropical Convergence Zone, Geophys Res. Lett., 30, 1125, doi:10.1029/2002GL016390, 2003.

Charria, G.: Influence of Rossby waves on the biogeochemical system in the North Atlantic Ocean: Use of ocean colour remotely sensed data and of a coupled physical/biogeochemical model, $\mathrm{PhD}$ thesis, University Paul Sabatier, Toulouse, France, 339 pp., 2005.

Charria, G., Dadou, I., Cipollini, P., Drévillon, M., De Mey, P., and Garçon, V.: Understanding the influence of Rossby waves on surface chlorophyll concentrations in the North Atlantic Ocean, J. Mar. Res., 64, 43-71, $2006 a$.

Charria, G., Dadou, I., Drévillon, M., Llido, J., and Garçon, V.: Coupled physical/biogeochemical modelling at mesoscale in the North Atlantic Ocean: Rossby waves, a coupled process example, Mercator Ocean Quarterly Newsletter, 20, 20-27, $2006 \mathrm{~b}$.

Charria, G., Dadou, I., Llido, J., Drévillon, M., and Garçon, V.: Importance of Dissolved Organic Nitrogen in the North Atlantic Ocean to sustain primary production: a 3D modeling view, Biogeosciences Discuss., 5, 1727-1764, 2008, http://www.biogeosciences-discuss.net/5/1727/2008/.

Chelton, D. B., Schlax, M. G., Samelson, R. M., and de Szoeke, R. A.: Global observations of large oceanic eddies, Geophys. Res. Lett., 34, L15606, doi:10.1029/2007GL030812, 2007.

Cipollini, P., Cromwell, D., Jones, M. S., Quartly, G. D., and Challenor, P. G.: Concurrent altimeter and infrared observations of Rossby wave propagation near $34^{\circ} \mathrm{N}$ in the Northeast Atlantic, Geophys. Res. Lett., 248, 889-892, 1997.

Cipollini, P., Cromwell, D., Challenor, P. G., and Raffaglio, S.: Rossby waves detected in global ocean colour data, Geophys Res. Lett., 28, 323-326, 2001.

Conkright, M. E., Garcia, H. E., O’Brien, T. D., Locarnini, R. A., Boyer, T. P., Stephens, C., and Antonov, J. I.: World Ocean Atlas 2001, Volume 4: Nutrients, edited by: Levitus, S., NOAA Atlas NESDIS 52, U.S. Government Printing Office, Wash., DC., 392 pp., CD-ROMS, 2002.

Ducet, N., Le Traon, P. Y., and Reverdin, G.: Global high-resolution mapping of ocean circulation from TOPEX/Poseidon and ERS-1 and -2, J. Geophys. Res., 105, 19477-19498, 2000.

Evans, G. T. and Parslow, J. S.: A Model of Annual Plankton Cycles, Biol. Oceanogr., 3, 327-347, 1985.

Hill, K. L., Robinson, I. S., and Cipollini, P.: Propagation characteristics of extratropical planetary waves observed in the ATSR global sea surface temperature record, J. Geophys. Res., 105, 21 927-21 945, 2000.

Huret, M., Dadou, I., Dumas, F., Lazure, P., and Garçon, V.: Coupling physical and biogeochemical processes in the Río de la Plata plume, Cont. Shelf Res., 25, 629-653, 2005.

Hurtt, G. C. and Armstrong, R. A.: A pelagic ecosystem model 
calibrated with BATS data, Deep-Sea Res. Pt II, 43, 653-683, 1996.

Isachsen, P. E., LaCasce, J. H., and Pedlosky, J.: Rossby wave instability and apparent phase speeds in large ocean basins, J. Phys. Oceanogr., 37, 1177-1191, 2007.

Kawamiya, M. and Oschlies, A.: Formation of a basin-scale surface chlorophyll pattern by Rossby waves, Geophys. Res. Lett., 28, 4139-4142, 2001.

Killworth, P. D. and Blundell, J. R.: Long Extratropical Planetary Wave Propagation in the Presence of Slowly Varying Mean Flow and Bottom Topography. Part II: Ray Propagation and Comparison with Observations, J. Phys. Oceanogr., 33, 802-821, 2003.

Killworth, P. D., Cipollini, P., Uz, B. M., and Blundell, J. R.: Physical and biological mechanisms for planetary waves observed in sea-surface chlorophyll, J. Geophys. Res., 109, C07002, doi:10.1029/2003JC001768, 2004.

Le Traon, P.-Y., Nadal, F., and Ducet, N.: An improved mapping method of multi-satellite altimeter data, J. Atmos. Oceanic Tech., 15, 522-534, 1998.

Lévy, M., Estubier, A., and Madec, G.: Choice of an advection scheme for biogeochemical models, Geophys. Res. Lett., 28, 3725-3728, doi:10.1029/2001GL012947, 2001.

Liebig, J.: On the chemical processes in the nutrition of vegetables, Chemistry in it applications to agriculture and physiology, edited by: Playfair, L., Peterson, PA, USA, 1845.

McClain, C. R., Cleave, M. L., Fledman, G. C., Gregg, W. W., Hooker, S. B., and Kurig, N.: Science quality SeaWiFS data for global biosphere research, Sea Technol., 39, 10-16, 1998.

Machu, E., Ferret, B., and Garçon, V.: Phytoplankton pigment distribution from SeaWiFS data in the subtropical convergence zone south of Africa: a wavelet analysis, Geophys. Res. Lett., 26, 1469-1472, 1999.

Madec, G. and Imbard, M.: A global ocean mesh to overcome the north pole singularity, Clim. Dynam., 12, 381-388, 1996.

Mellor, G. L. and Wang, X. H.: Pressure compensation and the bottom boundary layer, J. Phys. Oceanogr., 26, 2214-2222, doi:10.1175/1520-0485, 1996.

Mouriño-Carballido, B. and McGillicuddy Jr., D. J.: Mesoscale variability in the metabolic balance of the Sargasso Sea, Limnol. Oceanogr., 51, 2675-2689, 2006.
O’Reilly, J. E., Maritorena, S., Mitchell, B. G., Siegel, D. A., Carder, K. L., Garver, S. A., Kahru, M., and McClain, C.: Ocean color chlorophyll algorithms for SeaWiFS, J. Geophys. Res., 103, 24 937-24 953, 1998.

Oschlies, A.: Can eddies make ocean deserts bloom?, Global Biogeochem. Cy., 16, 1106, doi:10.1029/2001GB001830, 2002a.

Oschlies, A.: Nutrient supply to the surface waters of the North Atlantic: A model study, J. Geophys. Res., 107, 3046, doi:10.1029/2000JC000275, 2002b.

Oschlies, A. and Garçon, V.: Eddy-induced enhancement of primary production in a model of the North Atlantic Ocean, Nature, 394, 266-269, 1998.

Oschlies, A. and Garçon, V.: An eddy-permitting coupled physicalbiological model of the North Atlantic. 1. Sensitivity to advection numerics and mixed layer physics, Global Biogeochem. Cy., 13, 135-160, 1999.

Polito, P. S. and Cornillon, P.: Long baroclinic Rossby waves detected by TOPEX/POSEIDON, J. Geophys. Res., 102, 32153235, 1997.

Reynaud, T., Legrand, P., Mercier, H., and Barnier, B.: A new analysis of hydrographic data in the Atlantic and its application to an inverse modelling study, International WOCE Newsletters, 32, 1998.

Roussenov, V., Williams, R. G., Mahaffey, C., and Wolff, G. A.: Does the transport of dissolved organic nutrients affect export production in the Atlantic Ocean?, Global Biogeochem. Cy., 20, GB3002, doi:10.1029/2005GB002510, 2006.

Sakamoto, C. M., Karl, D. M., Jannasch, H. W., Bidigare, R. R., Letelier, R. M., Waltz, P. M., Ryan, J. P., and Polito, P. S.: Influence of Rossby waves on nutrient dynamics and the plankton community structure in the North Pacific subtropical gyre, J. Geophys. Res., 109, C05032, doi:10.1029/2003JC001976, 2004.

Siegel, D.: The Rossby Rototiller, Nature, 409, 576-577, 2001.

Torrence, C. and Compo, G. P.: A practical guide to wavelet analysis, B. Am. Meteorol. Soc., 79, 61-78, 1998.

Uz, B. M., Yoder, J. A., and Osychny, V.: Pumping of nutrients to ocean surface waters by the action of propagating planetary waves, Nature, 409, 597-600, 2001.

Williams, R. G., Roussenov, V., and Follows, M. J.: Nutrient streams and their induction into the mixed layer, Global Biogeochem. Cy., 20, GB1016, doi:10.1029/2005GB002586, 2006. 